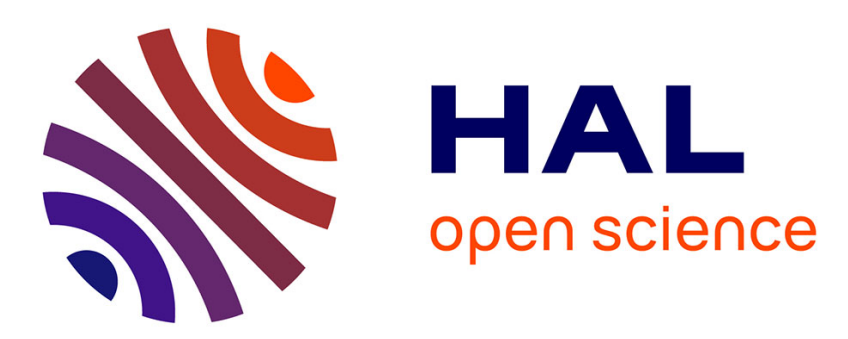

\title{
In vivo estrogen induction of hepatic estrogen receptor mRNA and correlation with vitellogenin mRNA in rainbow trout
}

Farzad Pakdel, Sylvie Féon, Florence Le Gac, Françoise Le Menn, Yves Valotaire

\section{To cite this version:}

Farzad Pakdel, Sylvie Féon, Florence Le Gac, Françoise Le Menn, Yves Valotaire. In vivo estrogen induction of hepatic estrogen receptor mRNA and correlation with vitellogenin mRNA in rainbow trout. Molecular and Cellular Endocrinology, 1991, 75, pp.205-212. 10.1016/0303-7207(91)90162-L . hal-02715541

\author{
HAL Id: hal-02715541 \\ https://hal.inrae.fr/hal-02715541
}

Submitted on 1 Jun 2020

HAL is a multi-disciplinary open access archive for the deposit and dissemination of scientific research documents, whether they are published or not. The documents may come from teaching and research institutions in France or abroad, or from public or private research centers.
L'archive ouverte pluridisciplinaire HAL, est destinée au dépôt et à la diffusion de documents scientifiques de niveau recherche, publiés ou non, émanant des établissements d'enseignement et de recherche français ou étrangers, des laboratoires publics ou privés. 


\title{
In vivo estrogen induction of hepatic estrogen receptor mRNA and correlation with vitellogenin mRNA in rainbow trout
}

\author{
Farzad Pakdel ${ }^{1}$, Sylvie Féon ${ }^{1}$, Florence Le Gac ${ }^{2}$, Françoise Le Menn ${ }^{3}$ \\ and Yves Valotaire ${ }^{1}$ \\ 'Laboratoire de Biologie Moléculaire, U.R.A. 256 C.N.R.S., Université de Rennes, 35042 Rennes Cedex, France, \\ ${ }^{2}$ Laboratoire de Physiologie des Poissons, I.N.R.A., Université de Rennes I, 35042 Rennes Cedex. France, \\ and ${ }^{3}$ Laboratoire de Biologie Marine, Institut de Biologie Animale et des Facultés, 33405 Talence Cedex, France
}

(Received 16 July 1990; accepted 9 November 1990)

Key words: Estrogen receptor; Vitellogenin; Rainbow trout

\section{Summary}

We have previously described the cloning, sequencing and in vitro expression of a full-length rainbow trout estrogen receptor cDNA (rtER cDNA). This full cDNA randomly labelled was used to study the estrogen induction of hepatic rtER mRNA in correlation with vitellogenin $(\mathrm{Vg}) \mathrm{mRNA}$ in different physiological situations. In this paper, we show that in the liver two mRNA species are under hormonal control and their level increases about 8-fold after estrogen stimulation. These two mRNAs are expressed and induced in the liver as early as the hatching stage in correlation with the expression of $\mathrm{Vg}$ mRNA. A long-term analysis of $r t E R ~ m R N A$ after estradiol $\left(E_{2}\right)$ injection shows a transient induction of the nuclear ER and its mRNA which recover to the basal level after 2 weeks. Nevertheless, a memory effect was observed on the expression of the $\mathrm{Vg}$ gene which does not appear to be directly related to the estrogen receptor level.

\section{Introduction}

The effect of steroids on their target tissues is mediated by hormone-specific receptor proteins, which, after associated with the steroid, acquire increased affinity for chromosomal binding sites. The hormone-receptor complex binds to specific sequences called hormone-responsive elements (HRE) which are generally localized upstream

Address for correspondence: Y. Valotaire, Université de Rennes I, U.R.A. 256 C.N.R.S., Lab. de Biologie Moléculaire, Campus de Beaulieu, 35042 Rennes Cedex, France. from the hormone-sensitive genes. These receptor/genome interactions are able to selectively stimulate the transcription rate of specific genes. Steroid hormone receptors currently represent some of the best understood models for nuclear receptor proteins containing metal binding fingers (for reviews sec Anderson, 1984; Yamamoto, 1985; Gorski et al., 1986; Green and Chambon, 1988). The identification of DNA sequences interacting with hormone receptors, cloning of receptors and transient expression of the receptor CDNA have increased our knowledge of the mechanism of action of the steroid receptors. However, the control of expression of the hormone receptor itself has received much less attention (Yamamoto, 
1985; Green and Chambon, 1986; Riegel et al., 1987; Barton and Shapiro, 1988).

In rainbow trout, as in other salmonids, there is no oviduct, and the liver is the main target organ for estrogens. In this organ, we have previously shown that vitellogenin gene expression is under estrogen control (Maitre et al., 1985; Le Guellec et al., 1988; Vaillant et al., 1988).

In Xenopus and chicken, the characteristics of vitellogenin $(\mathrm{Vg})$ induction by estrogens are different if animals have been previously treated with estrogen. Secondary induction is defined by the disappearance of the lag period and the increase in the accumulation rate of $\mathrm{Vg}$ mRNA revealing that liver cells retain a 'memory' of the primary stimulation (Tata and Smith, 1979; Shapiro, 1982; Evans et al., 1987). This memory effect persists for as long as 6 months and is passively maintained through cell division (Burch and Evans, 1986). Different hypotheses have been proposed to explain this phenomenon, for example either the maintaining of a high level of estrogen receptors (Westley and Knowland, 1979; Tata et al., 1987) or the presence of an estrogen-binding protein (Hayward et al., 1982), but persistent modification of the structure of the vitellogenin gene has also been suggested (Tata and Baker, 1975; Gerber et al., 1981; Burch and Weintraub, 1983).

We have previously described the cloning, sequencing and in vitro expression of a full-length random trout estrogen receptor cDNA (rtER cDNA) (Pakdel et al., 1990). This full cDNA randomly labelled was used to study the estrogen induction of hepatic rtER mRNA in correlation with vitellogenin $\mathrm{mRNA}$ in different physiological situations.

\section{Materials and methods}

\section{Animals and treatments}

Male and female rainbow trout (Oncorhynchus mykiss) were supplied by a trout farm (Gournaysur-Aronde, Oise, France). Male trout were stimulated using a saline $(\mathrm{NaCl} 9 \%$ ) injection of estradiol $\left(E_{2}\right)(0.5-1.5 \mathrm{mg} / \mathrm{kg}$ body weight). After hatching, the alvines were stimulated by the addition of $E_{2}$ to the water $(1.5 \mu \mathrm{M})$, left for $2 \mathrm{~h}$ and then transferred to $E_{2}$-free water. Their livers were collected 24 h later.

\section{$R N A$ preparation}

Total RNA was extracted using a modification of Auffray and Rougeon's technique (1980). Poly $\left(\mathrm{A}^{+}\right)$mRNA was obtained after affinity chromatography of the total RNA on oligo(dt) Trisacryl M (Aviv and Leder, 1972).

\section{Slot blot analysis}

Five to $10 \mu \mathrm{g}$ of total RNA was applied to a nylon membrane as described by Cheley and Anderson (1984). The amounts of rtER and $\mathrm{Vg}$ mRNA were obtained by comparison of slots with various amounts of $\mathbf{M}_{13} \mathrm{mp}_{19}$ containing rtER or $\mathrm{Vg}$ cDNA fragments.

\section{Northern blot analysis}

Poly $\left(\mathrm{A}^{+}\right)$RNA was subjected to $1 \%$ agarose gel electrophoresis in formaldehyde denaturing conditions, then transferred to a nylon membrane and hybridized in Thomas's conditions (1980).

\section{Labelling of $c D N A$ probe}

The rtER cDNA insert (Pakdel et al., 1989) and the Vg cDNA insert (Le Guellec et al., 1988) were labelled with the random primer labelling kit (Amersham), in the presence of $\left[\alpha-{ }^{32} \mathrm{P}\right] \mathrm{dCTP}(\sim$ $800 \mathrm{Ci} / \mathrm{mmol}$ ).

\section{Nuclear ER assay}

Nuclear extract preparation. The livers were homogenized in Tris-sucrose buffer $(2.5 \mathrm{ml} / \mathrm{g})(20$ $\mathrm{mM}$ Tris- $\mathrm{HCl} \mathrm{pH} 7.9,5 \mathrm{mM} \mathrm{CaCl}, 3 \mathrm{mM} \mathrm{MgCl}_{2}$, $330 \mathrm{mM}$ sucrose, $10 \mathrm{mM}$ monothioglycerol, $1 \mathrm{mM}$ phenylmethylsulphonyl fluoride (PMSF) using a polytron homogenizer $(5 \mathrm{~s})$ then a Potter homogenizer (1000 rpm, 20 plunges). After centrifugation $\left(15 \mathrm{~min}, 1000 \times \mathrm{g}, 4^{\circ} \mathrm{C}\right.$ ), the pellet was washed once with homogenization buffer containing $0.5 \%$ Triton and twice without Triton, then nuclei were extracted with $10 \mathrm{mM}$ Tris- $\mathrm{HCl} \mathrm{pH} 7.5,1.5 \mathrm{mM}$ EDTA, $500 \mathrm{mM} \mathrm{KCl}, 10 \mathrm{mM}$ monothioglycerol (1 $\mathrm{ml} / \mathrm{g}$ of initial liver) and centrifuged $(30 \mathrm{~min}$, $90,000 \times g, 4^{\circ} \mathrm{C}$ ). Supernatants were used for nuclear ER determination.

Estradiol binding. Preliminary binding kinetics had shown that more than $90 \%$ of the specific binding was obtained after $12 \mathrm{~h}$ of incubation and that desteroidization was not necessary for the nuclear extracts. $0.2 \mathrm{ml}$ of each nuclear extract 
was incubated with $3 \mathrm{nM}\left[{ }^{3} \mathrm{H}\right] \mathrm{E}_{2}(99 \mathrm{Ci} / \mathrm{mmol})$ without (total binding) or with (non-specific binding) $300 \mathrm{nM} \mathrm{E} \mathrm{E}_{2}$. After $12 \mathrm{~h}$ incubation at $4{ }^{\circ} \mathrm{C}$, free and bound hormones were separated by two successive dextran charcoal $(0.1-1 \%)$ treatments ( $5 \mathrm{~min}$ at $0^{\circ} \mathrm{C}$, centrifugation $5 \mathrm{~min}$ at $10,000 \times \mathrm{g}$ ). Supernatant radioactivity was determined in $4 \mathrm{ml}$ of Picofluor 30 and specific binding was calculated as the difference between total and nonspecific binding.

Estradiol level determination. $\mathrm{E}_{2}$ levels were determined using a radioimmunoassay (RIA) according to Terqui et al. (1973).

\section{Results}

\section{In vivo estradiol induction of rtER $m R N A s$}

A group of male rainbow trout, each weighing $250-350 \mathrm{~g}$, was stimulated by a single intraperitoneal injection of $17 \beta$-estradiol $(0.5 \mathrm{mg} / \mathrm{kg})$, a control group received the solvent only. The animals were sacrificed $24 \mathrm{~h}$ after treatment. 5-10 $\mu \mathrm{g}$ of liver total RNA or poly $\left(\mathrm{A}^{+}\right)$RNA was quantified by slot or Northern blot analysis with rtER probe. The rtER mRNA level increases about 8-fold $24 \mathrm{~h}$

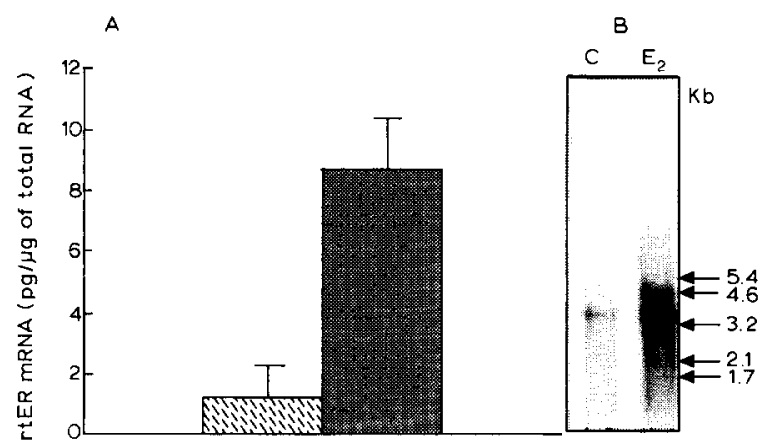

Fig. 1. Estrogen induction of hepatic rtER mRNA. $(A)$ Total RNA was isolated from control males (left-hand column) and $24 \mathrm{~h} \mathrm{E}_{2}$ (right-hand column) stimulated livers $\left(500 \mu \mathrm{g} \mathrm{E}_{2} / \mathrm{kg}\right.$ ). The amounts of rtER mRNA were estimated as described in Materials and Methods after slot blot hybridization and autoradiography. Values are given as mean \pm standard deviation ( $n=12$ for control males and $n=8$ for estrogen treated males). Means were compared using Student's $t$-test $(P<0.001)$. (B) Northern blot analysis of poly(A) RNA from (C) control and $\left(E_{2}\right)$ stimulated trouts. The markers used were a mixture of rRNA from rat $(5.4,2.1 \mathrm{~kb})$, trout $(4.6,2.1 \mathrm{~kb})$ and Escherichia coli $(3.2,1.7 \mathrm{~kb})$. after estrogen stimulation (Fig. $1 A$ ). In addition, Fig. $1 B$ reveals that the two species ( 3.5 and 4.5 kb) of rtER mRNA are under hormonal control.

\section{Detection and estradiol induction of $r t E R$ and $V g$} $m R N A$ after hatching

These experiments were performed in order to study ontogenesis of rtER mRNA and sensitivity of rtER and $\mathrm{Vg}$ genes to estradiol. After hatching (fry weighing only $50-150 \mathrm{mg}$ ), estrogen induction was performed as indicated in Materials and Methods by $E_{2}$ addition to the water. 50-100 livers, according to age, were pooled for RNA preparation. RtER and $\mathrm{Vg}$ mRNAs were quantified by slot blot analysis of $5 \mu \mathrm{g}$ of total RNA. As soon as the fish hatch, they have a basal level of ER mRNA in the liver comparable to that of either adult males or immature females (Fig. 2). This basal level increases during the first 2 weeks before recovering after 1 month. In addition, Fig. 2 shows that ER and $\mathrm{Vg}$ genes are always inducible by estrogen. After $24 \mathrm{~h}$, the levels of ER and $\mathrm{Vg}$ mRNA in the liver cells are identical to those found in adult fish stimulated for the same period. Both mRNA species ( 3.5 and $4.5 \mathrm{~kb}$ ) are also found and induced in the same proportion as in mature fish (Northern blot analysis, not shown).

\section{In vivo long-term analysis of rtER $M R N A$ stimula- tion}

A group of male rainbow trout $(600-900 \mathrm{~g})$ was injected with $\mathrm{E}_{2}(1.5 \mathrm{mg} / \mathrm{kg})$. Blood and livers were collected at the times indicated in Fig. 3 and plasma, nuclear extracts and total RNA prepared according to Materials and Methods. rtER and $\mathrm{Vg}$ mRNA, nuclear ER and plasma $E_{2}$ levels were determined. Nuclear ER and its mRNA are induced in parallel a few hours after hormone administration (Fig. $3 C$ and $A$ ). The levels increase until day 6 then recover to the basal value 3 weeks after hormonal injection. Fig. $3 B$ shows the transient expression of $\mathrm{Vg}$ gene after $\mathrm{E}_{2}$ administration. $\mathrm{Vg}$ mRNA induction follows that of rtER mRNA with a longer lag period. However, $\mathrm{Vg}$ mRNA accumulation is 1000 times greater and the decrease only starts after the second week. These results show the close relationship between the expressions of these two genes in the trout liver after $\mathrm{E}_{2}$ treatment. 
Memory effect after a second estradiol stimulation

As rtER mRNA and nuclear ER levels recover to basal values 3 weeks after $E_{2}$ treatment, we decided to investigate whether the $\mathrm{Vg}$ gene in rainbow trout was secondarily induced with a memory effect as described for $\mathrm{Vg}$ genes in Xenopus and chicken (Tata and Smith, 1979; Shapiro, 1982; Evans et al., 1987). Male rainbow trout $(600-900 \mathrm{~g})$ were first injected with $\mathrm{E}_{2}(1.5$ $\mathrm{mg} / \mathrm{kg}$ ) or with the same amount of solvent. A second injection was performed 1 month later with the same amount of $E_{2}$ or solvent. The fish
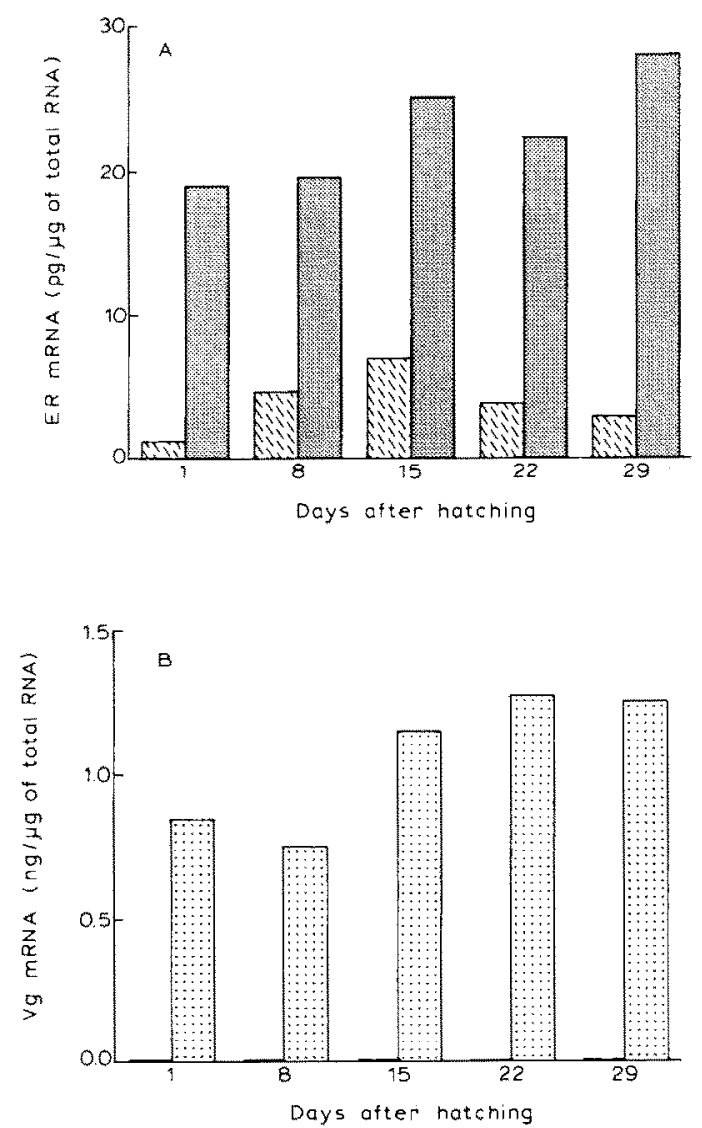

Fig. 2. Estradiol receptor ontogenesis in rainbow trout liver. At different periods after hatching, the alvines were stimulated with $\mathrm{E}_{2}$ according to Materials and Methods. 50-100 livers were pooled for each RNA extraction. (A) At the indicated times rtER mRNA was determined as described in Materials and Methods by slot blot hybridization. Left-hand columns: control; right-hand columns: $\mathrm{E}_{2}$ stimulated. $(B)$ At the indicated times $\mathrm{Vg}$ mRNA was determined as described in Materials and Methods by slot blot hybridization. Left-hand columns: control; right-hand columns: $E_{2}$ stimulated. were divided into four groups (Fig. 4): control animals injected with solvent at the first and second injection (I), animals injected with $E_{2}$ at the first injection and with solvent at the second injection (II), animals injected with solvent at the first injection and with $E_{2}$ at the second injection (III), and the last group treated with $E_{2}$ at the first and second injection (IV). For all animals, the livers were collected for RNA extraction $7 \mathrm{~h}$ after the second injection. The amounts of rtER and $\mathrm{Vg}$ mRNA were estimated after slot blot hybridization of $5 \mu \mathrm{g}$ total RNA with rtER and Vg probes and autoradiography. Fig. 4 shows that 1 month after the first injection the level of rtER mRNA decreased back to the basal level whereas $\mathrm{Vg}$ mRNA was undetectable (compare groups I and II in Fig. $4 A$ and $B$ ). The animals which received a second estrogen injection have an increased rtER mRNA level which is, however, no higher than after a first injection (compare groups IV and III in Fig. $4 A$ ). On the other hand, $\mathrm{Vg}$ mRNA is much greater after a second estrogen injection (compare groups IV and III in Fig. 4B). Thus the $\mathrm{Vg}$ gene memory effect does not appear to be directly related to the ER level.

\section{Discussion}

rtER mRNA level determination after $E_{2}$ treatment shows that, in contrast to the inhibitory effect of glucocorticoids (Okret et al., 1986) and progesterone (Wei et al., 1988), estrogen induces 10-20 times the basal level of their receptor mRNA. Northern blot analysis reveals the presence of two mRNAs in the liver. The specific function of these two mRNAs has not yet been determined but some preliminary observations indicate that they both code for estrogen receptors: their stimulation by estradiol is parallel, they both hybridize, in stringent conditions, with probes containing DNA or hormone binding domains (data not shown). In other species, the presence of multiple steroid receptor mRNA has also been described: in Xenopus four ER mRNAs from 2.5 to $9 \mathrm{~kb}$ (Weiler et al., 1987), in rat and man respectively two and three glucocorticoid receptor mRNAs from 4.8 to $7.1 \mathrm{~kb}$ (Hollenberg et al., 1985; Miesfeld et al., 1986). Progesterone receptor mRNA seems to be the more heterogeneous with 

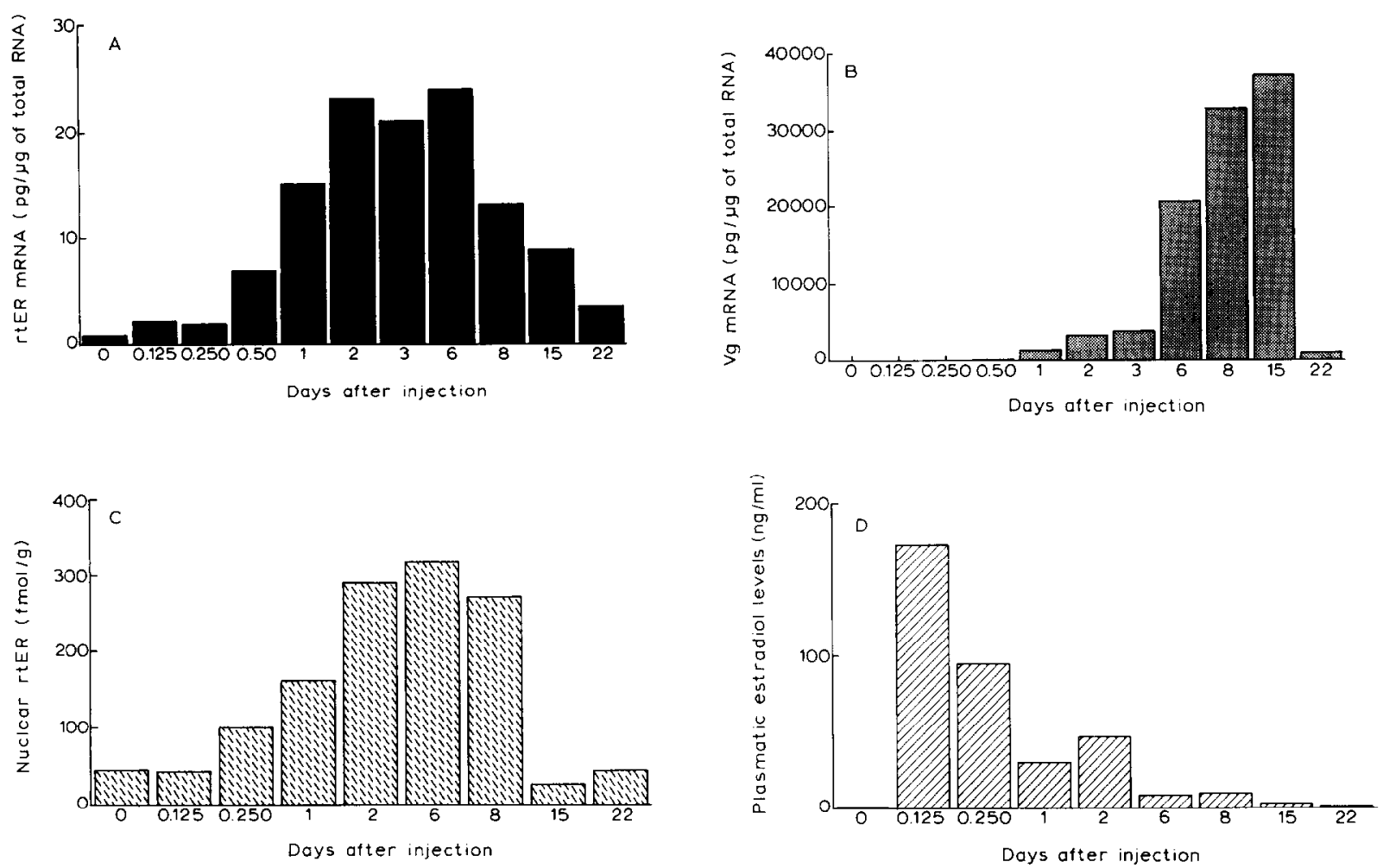

Fig. 3. Long-term analysis of $\mathrm{rtER}$ and $\mathrm{Vg}$ mRNA stimulation in vivo. Male rainbow trout $(600-900 \mathrm{~g})$ were injected with $\mathrm{E}_{2}$ (1.5 $\mathrm{mg} / \mathrm{kg}$ ). The blood and livers were removed at the indicated times. Total RNA and nuclear extracts were prepared as described in Materials and Methods. rtER $(A)$ and $\mathrm{Vg}(B)$ mRNA levels were determined as described in Materials and Methods by slot hybridization, the nuclear estrogen receptor levels in liver $(C)$ were measured by incubation with $3 \mathrm{nM}\left[{ }^{3} \mathrm{H}\right] \mathrm{E}_{2}$ in the presence or absence of a 100 -fold excess $\left[{ }^{1} \mathrm{H}\right] \mathrm{E}_{2}$ at $2{ }^{\circ} \mathrm{C}$ for $12 \mathrm{~h}$, and plasma $\mathrm{E}_{2}$ levels $(D)$ were measured by radioimmunoassay. Each determination is the mean of two independent experiments.

four messengers from 1.8 to $8 \mathrm{~kb}$ in the chicken (Conneely et al., 1986, 1987) and six from 2.5 to $11.4 \mathrm{~kb}$ in man (Misrahi et al., 1987; Wei et al., 1988). The origin and functions of these multiple steroid receptor mRNAs are not yet well known. However, recent works show that two forms of human progesterone receptor (hPR), differing in their $\mathrm{N}$-terminal region and proceeding from two classes of hPR mRNAs, exhibit different functional properties (Kastner et al., 1990). Cloning of several steroid receptor's genes reveals that these mRNAs are likely to be transcribed from a unique gene (Huckaby et al., 1987; Ponglikitmongkol et al., 1988; Kuiper et al., 1989) and they might result from the use of different transcription initiation sites (Kastner et al., 1990) or of different polyadenylation sites (Hollenberg et al., 1985). They can also arise from a differential splicing of the same primary transcript (Mitsuhashi et al., 1988). In the rainbow trout, the higher molecular weight mRNA is only observed in the liver while the lower molecular weight mRNA is found in the hypothalamus immature male gonads and pituitary; in the latter tissue a shorter $1.4 \mathrm{~kb}$ mRNA is also observed (Pakdel et al., 1990).

The rtER gene is expressed in the liver as early as at hatching. The basal levels of rtER mRNA are very similar to those found in the adult, and on Northern blot (result not shown) the presence of the two rtER mRNAs was noted. $r t E R$ and $\mathrm{Vg}$ genes also seem to be fully induced as early as at hatching and our results show that the estrogen response arises independently of sexual maturation which occurs later during development (Van den Hurk et al., 1982). These results are in good agreement with previous studies on chicken yolk 

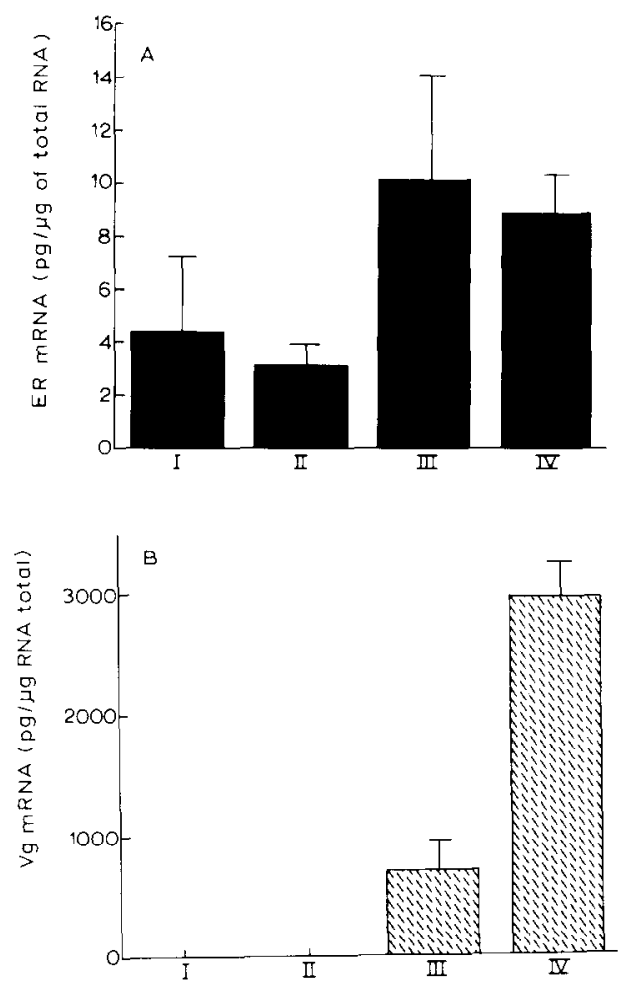

Fig. 4. Memory effect after a second $E_{2}$ stimulation. Male rainbow trout $(600-900 \mathrm{~g})$ were injected with $E_{2}(1.5 \mathrm{mg} / \mathrm{kg})$ or with the solvent. $A$ second injection was performed 1 month after the first injection. The animals were divided into four groups. The livers were collected for RNA extraction $7 \mathrm{~h}$ after the second injection. (I) Control animals were injected with solvent at first and second injection. (II) Animals were injected with $E_{2}$ at first injection and with solvent at second injection. (III) Animals were injected with solvent at first injection and with $\mathrm{E}_{2}$ at second injection. (IV) Animals were injected with $\mathrm{E}_{2}$ at first and second injection. The amounts of $\mathrm{rtER}(A)$ and $\mathrm{Vg}(B)$ mRNA were estimated as described in Materials and Methods after slot blot hybridization and autoradiography. Values are given as mean \pm standard deviation $(n=4)$. Four animals are used for each determination and value.

protein regulation (Elbrecht et al., 1984). However, in the rainbow trout, further studies of primary and secondary inductions are necessary to determine the kinetics of stimulation and to confirm that there is no variation in sensitivity of ER and $\mathrm{Vg}$ genes after hatching, in contrast to the results obtained with the chicken (Evans et al., 1987). Further studies are also necessary to determine if the presence of ER is sufficient during early embryogenesis for $\mathrm{Vg}$ gene induction or if another mechanism such as chromatin structure modification is also necessary (Weisbord, 1982). In the Xenopus tadpole, for instance, ER has been observed in the liver before metamorphosis (stage 54 ); however, estrogens are only able to induce $\mathrm{Vg}$ synthesis during metamorphosis (stage 62) (May and Knowland, 1981; Riegel et al., 1987). In rainbow trout, these studies are not easy owing to the small size of the embryos, but in situ hybridization is a possible alternative.

Estrogen stimulation kinetics in the adult male rainbow trout show a transient induction of $r E R$ mRNA and nuclear ER preceding $\mathrm{Vg}$ mRNA transcription. $\mathrm{Vg}$ mRNA accumulation continues until day 15 when the nuclear ER and ER mRNA have already recovered to basal levels. This may be explained by an increase in the $\mathrm{Vg}$ mRNA half-life. Comparison of the induction levels of the two genes shows that the $\mathrm{Vg}$ gene is expressed about 1000 times more under estrogen treatment than the ER gene, indicating the differential strength of the two promoters. In the rtER promoter, Le Pennec et al. (personal communication) have shown the presence of potential imperfect ERE which may explain the weak induction of the rtER gene compared to the Vg gene.

After $E_{2}$ induction, the nuclear receptor and rtER mRNA levels decrease and return to the basal value 2 or 3 weeks after $E_{2}$ treatment, which may be due to the gradual disappearance of $E_{2}$ following injection (Fig. 3D). A negative feedback, by binding and competition of free receptors to ERE when the $\mathrm{E}_{2}$ concentration becomes too small, may be involved as it has been shown that free receptors can bind ERE without gene transcription activation (Kumar et al., 1987). Nevertheless, our results are different from those described in Xenopus (Barton and Shapiro, 1988). In this species, it has been shown that Xenopus estrogen receptor (XER) mRNA induction in the liver is permanent and stable for at least 4 months after $E_{2}$ treatment; then $V g$ gene activation is transient. After a first stimulation, the low level of endogenous estrogen is sufficient to maintain activation of the XER gene but not that of the $\mathrm{Vg}$ gene. This hypothesis is supported by experiments in liver cell culture where the induction of XER mRNA is maintained with $0.2 \mathrm{nM} \mathrm{E}_{2}$ but $\mathrm{Vg}$ mRNA is not (Barton and Shapiro, 1988). In the rainbow trout, preliminary results with cultured 
hepatocytes show that rtER mRNA is primarily induced with lower doses of estrogen $\left(10^{-10} \mathrm{M}\right)$ than $\mathrm{Vg}$ mRNA is (results not shown). Further experiments are necessary to determine if there is a specific sensitivity of the two genes after a first treatment by estrogens. However, while the level of rtER mRNA is not maintained and returns to the basal value 3 weeks after primary injection, we still observed a memory effect on the induction of $\mathrm{Vg}$ gene following the second injection. To explain this memory effect, we cannot invoke the presence of a higher level of receptors at the time of the second injection as in Xenopus or chicken liver (Westley and Knowland, 1979; Hayward et al., 1982; Tata et al., 1987). Persistent structure modification of the $\mathrm{Vg}$ gene, or the presence of additional transcription factors, is more likely to explain the phenomenon.

\section{Acknowledgements}

The authors thank Mrs. J. Sorais for typing the manuscript. This work was supported by the Groupement de Coopération Scientifique, Bases Biologiques de l'Aquaculture.

\section{References}

Anderson, J.N. (1984) in Hormone Action, Vol. 3B (Goldberg, R.F. and Yamamoto, K.R., eds.), pp. 169-212, New York - London.

Auffray, C. and Rougeon, F. (1980) Eur. J. Biochem. 107, 303-314.

Aviv, H. and Leder, P. (1972) Proc. Natl. Acad. Sci. U.S.A. 69, $1408-1412$.

Barton, M.C. and Shapiro, D.J. (1988) Proc. Natl. Acad. Sci. U.S.A. 85, 7119-7123.

Burch, J.B.E. and Evans, M.I. (1986) Mol. Cell. Biol. 12, 1117-1135.

Burch, I.B.F. and Weintraub, H. (1983) Cell 33, 65-76.

Cheley, S. and Anderson, R. (1984) Anal. Biochem. 137, 15-19.

Conneely, O.M., Sullivans, W.P., Toft, D.O., Birnbaumer, M., Cook, W.T. and O'Mallcy, B.W. (1986) Science 233, 767770 .

Conneely, O.M., Dobson, A.D.W., Tsai, M.J., Beattie, W.G., Toft, D.U., Huckaby, C.S., Zaruki, T., Schrader, W.T. and O'Malley, B.W. (1987) Mol. Endocrinol. 1, 517-525.

Elbrecht, A., Lazier, C.B., Protter, A. and Williams, D.L. (1984) Science 225, 639-641.

Evans, M.I., O'Malley, P.J., Krust, A. and Burch, J.B.E. (1987) Proc. Natl. Acad. Sci. U.S.A. 84, 8493-8497.

Gerber-Hubert, S., May, F.E.B., Westley, B.R. Felber, B.K.,
Hosbach, H.A., Anders, A.C. and Ryffel, G.U. (1983) Cell 33. 44-51.

Gorski, J., Welshons, W.V., Sakai, D., Hansen, J., Walent, J., Kassis, J., Shull, J., Stack, G. and Campen, C. (1986) Recent Prog. Horm. Res. 42, 297-329.

Green, S. and Chambon, P. (1986) Nature 324, 615-617.

Hayward, M.A., Brock, M.L. and Shapiro, D.J. (1982) Am. J. Physiol. 243, C1-C6.

Hollenberg, S.M., Weinberger, C., Ong, E.S., Cerelli, G., Oro, A., Lebo, R., Thompson, E.B., Rosenfeld, M.G. and Evans, R.M. (1985) Nature 318, 635-641.

Huckaby, C.S., Conneely, O.M., Beattie, W.G., Dobson, A.D.W., Tsai, M.J. and O'Malley, B.W. (1987) Proc. Natl. Acad. Sci. U.S.A. 84, 8380-8384.

Kastner, P., Krust, A., Turcotte, B., Stropp, U., Tora, L., Gronemeycr, H, and Chambon, P. (1990) EMBO J. 9, $1603-1614$.

Kuiper, G.G.J.M., Faber, P.W., Van Rooij. H.C.J., Van der Korput, J.A.G.M., Ris-Stalpers, C., Klaassen, P., Trapman, J. and Brikmann, A.O. (1989) J. Mol. Endocrinol. 2, R1-R4.

Kumar, V., Green, S., Stack, G., Berry, M., Jin, J.R. and Chambon, P. (1987) Cell 51, 941-951.

Le Guellec, K., Lawless, K., Valotaire, Y., Kress, M. and Tenniswood, M. (1988) Gen. Comp. Endocrinol. 71, 359371.

Leonard, W.J., Depper, J.M., Kanehisa, M., Kronke, M., Peffer, N.J., Svetlik, P.B., Sullivan, M. and Greenc, W.C. (1985) Science 230, 633-639.

Maitre, J.L., Mercier, L., Dolo, L. and Valotaire, Y. (1985) Biochimie 67, 215-225.

May, F.E.B. and Knowland, J. (1981) Nature 292, 853-855.

Miesfeld, R., Rusconi, S., Godowski, P.J., Maler, B.A., Okret, S., Wikström, A.C., Gustafsson, J.A. and Yamamoto, K.R. (1986) Cell 46, 389-399.

Misrahi, M., Atger, M., D'Auriol, L., Loosfelt, H., Meriel, C., Fridlansky, F., Guiochon-Mantel, A., Galibert, F. and Milgrom, E. (1987) Biochem. Biophys. Res. Commun. 143, 740-748.

Mitsuhashi, T., Tennyson, G.E. and Nikodem, V.M. (1988) Proc. Natl. Acad. Sci. U.S.A. 85, 5804-5808.

Okret, S., Poellinger, L., Dong, Y. and Gustafsson, J.A. (1986) Proc. Natl. Acad. Sci. U.S.A. 83, 5899-5903.

Pakdel, F., Le Guellec, C., Vaillant, C., Le Roux, M.G. and Valotaire, Y. (1989) Mol. Endocrinol. 3, 44-51.

Pakdel, F., Le Gac, F., Le Goff, P. and Valotaire, Y. (1990) Mol. Cell. Fndocrinol. 71, 195-204.

Ponglikitmongkol, M., Green, S. and Chambon, P. (1988) Mol. Cell. Biol. 8, 4510-4517.

Riegel, A.T., Aitken, S.C., Martin, M.B. and Schoenberg, D.R. (1987) Endocrinology 120, 1283-1290.

Shapiro, D.J. (1982) CRC Crit. Rev. Biochem. 12, 187-203.

Tata, J.R. and Baker, B.S. (1975) Biochem. J. 50, 345-355.

Tata, J.R. and Smith, D.F. (1979) Recent Prog. Horm. Res. 35, 47-95.

Tata, J.R., Ng, C.N., Perlman, A.J. and Wolffe, A.P. (1987) in Gene Regulation by Steroid Hormone, Vol. 3 (Roy, A.K. and Clark J.H.. eds.). pp. 205-233. Springer-Verlag. New York. 
Terqui, M., Dray, F. and Cotta, J. (1973) CR Acad. Sci. Paris Sér. D. 277, 1795-1798.

Thomas, P.S. (1980) Proc. Natl. Acad. Sci. U.S.A. 77, 52015205.

Vaillant, C, Le Guellec, C., Pakdel, F. and Valotaire, Y. (1988) Gen. Comp. Endocrinol. 70, 284-290.

Van den Hurk, R, Lambert, G.D. and Peute, J. (1982) Reprod. Nutr. Dev. 22, 413-425.

Wei, L.L., Krett, N.L., Francis, M.D., Gordon, D.F., Wood,
W.M., O'Malley, B.W. and Horwitz, K.B. (1988) Mol. Endocrinol. 2, 62-72.

Weiler, 1.J., Lew, D. and Shapiro, D.J. (1987) Mol. Endocrinol. $1,355-361$.

Weisbord, S. (1982) Nature 297, 289-295.

Westley, B. and Knowland, J. (1979) Biochem. Biophys. Res. Commun. 88, 1167-1172.

Yamamoto, K.R. (1985) Annu. Rev. Genet. 19, 209-252. 